\title{
Carbonate $\mathrm{P} / \mathrm{Ca}$ as a proxy for phosphate levels in the Archean
}

\author{
MIQUELA INGALLS ${ }^{1}$, WOODWARD FISCHER ${ }^{2}$ AND \\ JOHN GROTZINGER ${ }^{2}$
}

${ }^{1}$ Pennsylvania State University
${ }^{2}$ California Institute of Technology
Presenting Author: ingalls@psu.edu

Phosphate is essential to form and sustain life. However, the chemical environment on early Earth necessary to sustain sufficient phosphate concentrations required for prebiotic phosphorylation of organic molecules is enigmatic, because any $\mathrm{Ca}^{2+}$ would titrate phosphate as apatite. Toner \& Catling (2020, $P N A S$ ) suggested that alkaline lakes under early Earth $\mathrm{pCO}_{2}$ conditions would foster molal $\mathrm{PO}_{4}{ }^{3-}$ concentrations because carbonate minerals would instead consume $\mathrm{Ca}^{2+}$. We recently demonstrated that elevated $\mathrm{PO}_{4}{ }^{3-}$ concentrations are incorporated into the diverse carbonate phases and textures precipitated from hyperalkaline lakewater (Ingalls et al., 2020, GRL). Thus, inorganic $\mathrm{P} / \mathrm{Ca}$ measurements can inform both the phosphate content and calcium-to-alkalinity ratios (Ca:ALK) of carbonateforming environments in the rock record.

We tested deep-time $\mathrm{P} / \mathrm{Ca}$ preservation in carbonate facies similar to those found on Archean shallow carbonate platforms in the substantially younger and better preserved Eocene Green River Formation. Aragonite fans, oolites, early diagenetic dolospar, and lumpy laminations yield $\mathrm{P} / \mathrm{Ca}$ of $0.211 \pm 0.027$ to $0.533 \pm 0.094 \mathrm{mmol} / \mathrm{mol}$, comparable to $\mathrm{P} / \mathrm{Ca}$ of Pleistocene tufas precipitated from low Ca:ALK lakewater (Ingalls et al., 2020). Thus, diverse carbonate facies formed in an alkaline phase of the Eocene Green River Formation preserve expected P/Ca values.

Finally, to assess the paleo-Ca:ALK of the large, long-lived carbonate platforms that preserve some of the earliest evidence of the microbial biosphere, we measured marine calcite cements and microbialites in the Archean Transvaal Supergroup (S. Africa; mean, $0.138 \pm 0.075 \mathrm{mmol} / \mathrm{mol}$ ), Carawine Dolomite (Australia; $0.201 \pm 0.168 \mathrm{mmol} / \mathrm{mol}$ ), and Mosher Formation of the Steep Rock Group (Canada; 0.099 $\pm 0.019 \mathrm{mmol} / \mathrm{mol}$ ). P/Ca was highest in the cements and lowest in later veins, with a total range from 0.028 to $0.474 \mathrm{mmol} / \mathrm{mol}$ in all microfacies. The relatively low $\mathrm{P} / \mathrm{Ca}$ ratios of Archean shallow marine carbonates are comparable to four times as elevated as abiotic modern marine carbonates, but $\sim 10$ to 40 times greater than modern, shallow reef facies. Although our results do not indicate that Archean shallow marine environments were particularly alkaline, the order of magnitude greater than modern phosphate levels may indicate sufficient phosphate for prebiotic phosphorylation on shallow carbonate platforms. 